\title{
Basic and clinical immunology - 3021. Inhibitory action of levocetirzine hydrochloride on eosinophil actication in vitro
}

\author{
Atsuko Furuta ${ }^{1 *}$, Kazuhito Asano ${ }^{2}$, Harumi Suzaki ${ }^{2}$ \\ From 2nd WAO International Scientific Conference (WISC 2012) \\ Hyderabad, India. 6-9 December 2012
}

\section{Background}

Histamine $\mathrm{H}_{1}$ receptor antagonists are used for the treatment of allergic disorders such as allergic rhinitis and atopic allergy with remarkable success. However, the influence of antihistamines on the function of eosinophils, which are the most important final effector cells in allergic diseases, is not well understood.

\section{Purpose}

The influence of histamine $\mathrm{H}_{1}$ receptor antagonists on eosinophil functions was examined through the choice of levocetirizine hydrochloride (LH) in vitro and in vivo.

\section{Methods}

$\mathrm{BALB} / \mathrm{c}$ male mice (5 weeks of age) were intraperitoneally infected with 500 Mesocestoides cortii larvae. These mice were then treated with $\mathrm{LH}$ at a single dose of $0.1 \mathrm{mg} / \mathrm{kg}$ once a day, which was started on the day of infection. The percent of peripheral blood eosinophils and IgE levels were examined 21 days after infection. In the second experiments, eosinophils obtained from mice infected with $M$ cortii were sensitized with M.cortii-specific IgE, and these sensitized eosinophils were stimulated with $10 \mathrm{ng} / \mathrm{ml}$ of $M$. cortii excretory antigen in the presence of $\mathrm{LH}$ for $24 \mathrm{~h}$. MIP-1 $\beta, \mathrm{LTC}_{4}$ and RANTES levels in culture supernatants were examined by ELISA.

\section{Results}

Oral administration of LH could not suppress both peripheral blood eosinophila and IgE hyper-production, which were observed in mice infected with $M$ cortii. The addition of LH into cell cultures could suppress the ability

'Department of Otorhinolaryngology, School of Medicine, Showa University, Tokyo, Japan

Full list of author information is available at the end of the article of eosinophils to produce MIP-1 $\beta, \mathrm{LTC}_{4}$ and RANTES, which were increased by SCF stimulation. The minimum concentrations of $\mathrm{LH}$, which caused significant suppression of factor production, were $1.0 \mu \mathrm{M}$ for MIP- $1 \beta$ and $\mathrm{LTC}_{4}$, and $0.5 \mu \mathrm{M}$ for RANTES.

\section{Conclusions}

These results may suggest that LH exerts inhibitory effects on eosinophil activation and results in favorable modification of clinical status of pollinosis patients.

\section{Author details}

'Department of Otorhinolaryngology, School of Medicine, Showa University, Tokyo, Japan. ${ }^{2}$ Physiology, Showa University, Japan.

Published: 23 April 2013

doi:10.1186/1939-4551-6-S1-P197

Cite this article as: Furuta et al.: Basic and clinical immunology - 3021. Inhibitory action of levocetirzine hydrochloride on eosinophil actication in vitro. World Allergy Organization Journal 2013 6(Suppl 1):P197.

Submit your next manuscript to BioMed Central and take full advantage of:

- Convenient online submission

- Thorough peer review

- No space constraints or color figure charges

- Immediate publication on acceptance

- Inclusion in PubMed, CAS, Scopus and Google Scholar

- Research which is freely available for redistribution

\section{Biomed Central}

(c) 2013 Furuta et al; licensee BioMed Central Ltd. This is an Open Access article distributed under the terms of the Creative Commons Attribution License (http://creativecommons.org/licenses/by/2.0), which permits unrestricted use, distribution, and reproduction in any medium, provided the original work is properly cited. 